\title{
EXPLORING PROJECT-RELATED FACTORS THAT INFLUENCE LEADERSHIP STYLES AND THEIR EFFECT ON PROJECT PERFORMANCE: A CONCEPTUAL FRAMEWORK
}

\author{
S. Pretorius ${ }^{1 * \#}$, H. Steyn ${ }^{1} \&$ T.J. Bond-Barnard ${ }^{1}$
}

\section{ARTICLE INFO}

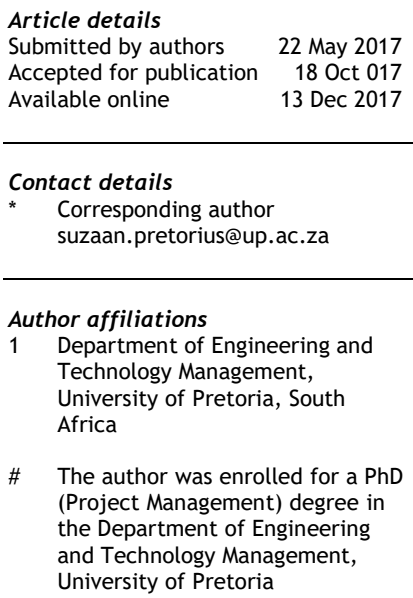

DOI

http://dx.doi.org/10.7166/28-4-1778
ABSTRACT

It is widely accepted that project leaders should adapt their behaviour to meet the unique leadership demands of a variety of situations. Recently, vertical, shared, and horizontal styles of leadership have gained prominence, especially in the project management literature. Several factors are believed to play a role in determining an appropriate balance between these leadership styles. This theoretical study explores the influence of project types, the stage in the project life cycle, organisational project management maturity, and the level of trust and collaboration between project team members on the appropriate balance of leadership styles in projects. This paper presents a conceptual framework of these factors, while empirical results will be reported on in the sequel to this paper.

\section{OPSOMMING}

Dit word wyd aanvaar dat leiers hulle gedrag by spesifieke situasies moet aanpas sodat die unieke leierskapvereistes wat aan hulle gestel word nagekom kan word. Vertikale, gedeelde en horisontale leierskap style is deesdae op die voorgrond, veral in projekbestuur literatuur. Verskeie faktore speel ' $n$ rol in die bepaling van 'n geskikte balans tussen hierdie leierskapstyle. Die faktore sluit in die tipe projek, die stadium in die projeklewensiklus, die projekbestuurvolwassenheid van die organisasie, en die vlak van vertroue en samewerking tussen mense binne die projek. Hierdie artikel stel 'n konseptuele raamwerk van hierdie faktore voor, terwyl empiriese uitslae in 'n opvolgartikel gerapporteer sal word.

\section{INTRODUCTION}

Leadership can be seen as the practice of influencing others to agree about work and how it can be done effectively, and as the process of enabling individual and collective efforts to accomplish a shared objective [1]. According to Crevani et al. [2], modern leadership theory started developing during the Industrial Revolution, mostly when economists began to pay attention to leadership theory. There has been an evolving movement towards viewing leadership in terms of collaboration between two or more persons, while the concept remains typically concerned with command and control [2].

Today the role of leadership is gaining interest in project management research. In 2000 only 26 research articles used the terms 'leadership' and 'project management' in their titles, while in 2015 the use of these terms grew to 271 [3]. According to Müller et al. [3], project management research is increasingly investigating the role of leadership in project management. Two major streams have developed: shared leadership, and vertical leadership. The concept of horizontal leadership has been investigated to some extent $[3,4,5,6,7]$. Traditionally, research has taken a person-centred approach to project leadership by highlighting the role of the project manager in accomplishing project outcomes, while the current focus is more on shared leadership within the project team [3]. 
This study focuses on the effect that projects and related organisational properties have on leadership style. Personal and interpersonal factors (e.g., personality types and emotional intelligence) and technical engineering factors are beyond the scope of the study.

\subsection{Vertical leadership}

When an organisational hierarchy is in place, leadership may be described as more 'vertical'. In such a hierarchy, a formally appointed leader functions as the main source of instruction, oversight, and control for those reporting to him or her. Customarily these leaders influence projects in a downward, 'one-to-many' style [8], [9]. Employees in the higher organisational levels may assist as a source of control and oversight for other team members, while the appointed leader delegates specific tasks to other group members. In essence the leader oversees the activities of the group, and the group executes the orders of this leader. The individual at the top is the primary source of information for group members. This implies, in its extreme form, that other team members are not granted the opportunity to evaluate information and reach consensus about a decision made through a process of top-down influence (team members merely follow orders) [1].

\subsection{Shared leadership}

In shared leadership there is a cooperative state of mutual influence, in which the leadership role emerges from individuals in the team [9]. All team members participate in the decision-making process (collaborative decision-making), they take over tasks that the vertical leader would traditionally have done, share accountability for outcomes, and, when necessary, offer guidance to other team members to achieve group goals [10], [11]. The team members cooperatively share duties and responsibilities [12].

In this leadership style the team members nominate a specific team member to take over leadership at a specific point in time [9]. In a project management environment, different skills are needed at different points in the project life cycle. Shared leadership is practised when leadership is transferred between those with the required skills, as dictated by either environmental demands or the developmental stage of the team at any given time [6], [13]. When the situation warrants it, team members step forward and provide the required leadership, and then step back to allow others to assume the leadership role [14]. This shift in leadership role may happen many times during the progression towards goal realisation or mission completion [13].

According to Locke [15], shared leadership displays the following characteristics:

- Constant teamwork;

- The focus is on the group and not on the individual;

- Team members share information;

- Team members are all equal and interdependent;

- Independence is frowned upon;

- Each team member influences the others equally;

- There is joint decision-making; and

- Team members have social skills.

\subsection{Horizontal leadership}

Little has been written to date on the differences between shared and horizontal leadership, probably as a result of the novelty of this distinction. According to Müller [9], horizontal leadership is executed by a team member upon nomination by the project manager (vertical leader), and governed by the vertical leader for the time of the nomination. This leadership style has a closer connection with vertical leadership than is described in the traditional shared leadership theories [9]. In contrast, shared leadership is a collective activity, and shifting control to the appropriate team members is necessary in this leadership style [7].

Horizontal leadership incorporates the distributed form of leadership in projects, where one or several members of the project team influence the project manager, and the rest of the team execute the project in a particular manner [7]. Team members take on the leadership role in a project on behalf of the project manager (vertical leader) based on their skills that are needed at a certain point in time [5]. The role of the vertical leader is constantly to maintain horizontal leadership by keeping the general vision and direction, prompting the shift of leadership from vertical leadership to horizontal leadership by involving the team in the quest for solutions, and 
managing the fairness of the leadership assignments [6]. Horizontal leadership is enabled through empowerment by the project manager and executed through self-management by the team [6].

\subsection{Comparison of shared and horizontal leadership}

The differences between shared and horizontal leadership are summarised in Table 1.

Table 1: The differences between shared and horizontal leadership

\begin{tabular}{|l|l|}
\hline \multicolumn{1}{|c|}{ Shared leadership } & \multicolumn{1}{c|}{ Horizontal leadership } \\
\hline $\begin{array}{l}\text { Executed by a team member upon nomination } \\
\text { by the team members [9]. }\end{array}$ & $\begin{array}{l}\text { Executed by a team member upon nomination } \\
\text { by the vertical leader [9]. }\end{array}$ \\
\hline $\begin{array}{l}\text { Balance of autonomy and accountability exists, } \\
\text { and these characteristics are distributed among } \\
\text { all team members [10]. }\end{array}$ & $\begin{array}{l}\text { Governed by the vertical leader for the time of } \\
\text { the nomination of the temporary team leader } \\
\text { [9]. }\end{array}$ \\
\hline $\begin{array}{l}\text { Leadership is a collective activity, and shifting } \\
\text { control to the appropriate team members is } \\
\text { necessary [7]. }\end{array}$ & $\begin{array}{l}\text { Closer connection with vertical leadership [9]. } \\
\end{array}$ \\
\hline
\end{tabular}

In both shared and horizontal leadership the leadership role is continually transferred between team members, based on the critical skills needed at different points in the project [3], [5].

\subsection{The balance between the leadership styles}

We acknowledge the differences between shared and horizontal leadership as explained in Table 1 . However, in order to limit the scope of this study, and due to the limited use of the concept of horizontal leadership in the literature, no distinction will be made between these two leadership styles in the rest of this paper. 'Shared leadership' will be used to refer to both these styles.

While some scholars view vertical and shared leadership as distinctly separate styles, in reality project leaders frequently have to use the different styles of leadership simultaneously; shared leadership often complements, but does not replace, vertical leadership. According to Hsu et al. [16], shared leadership cannot be maintained at all times. In addition, teamwork goals may suffer as a result of absent or weak shared leadership. Shared leadership will most often not be successful when individual team members have different or inconsistent understandings of the goals and priorities of their tasks. It therefore can be concluded that shared leadership enhances vertical leadership [16].

No single individual possesses the competency to play all possible leadership roles efficiently within a group or organisation. This is due to the fact that an individual (the formally appointed vertical leader) is unlikely to have the required skills and strengths in all the necessary areas. The vertical leader may also have strong preferences for certain leadership tasks and not for others. Most teams are also composed of team members who are multifunctional, highly skilled, and have strong leadership abilities. It therefore makes sense to apply the individual members' strengths to supplement the vertical leader's capabilities [17]. Furthermore, a vertical leader could complete necessary project tasks when team members are not competent or able to perform certain sharedleadership functions. It should typically be expected that vertical leaders will intervene when shared leadership is inhibited or absent [16].

According to Müller et al. [3], projects rarely depend on only one or the other form of leadership; most of the time a mix of vertical and shared leadership is used (see Figure 1). One way in which shared leadership manifests itself is when the vertically-inclined leader shares with, or solicits information from, other group members [18]. Shared leadership is thus empowered by vertical leadership [3]. Figure 1 illustrates the notion of a continuum between vertical and shared leadership: it is not one or the other, and there should be an appropriate balance, with the leadership style tailored to the circumstances [18]. 


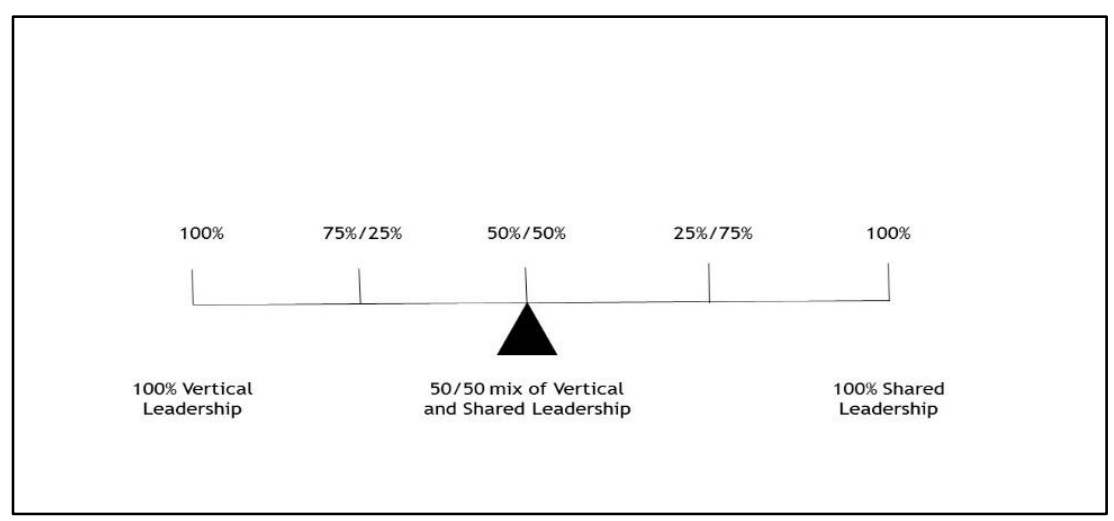

Figure 1: The balance between vertical and shared leadership

\subsection{Objective of the study}

The objective of this study is to establish a conceptual model for project-related factors that influence leadership styles and their effect on project performance. It is intended for both scholars and practitioners.

According to Müller et al. [6], studies on balanced leadership are limited, and are not linked to a general framework that would allow researchers to hypothesise and practitioners to use it intentionally for the advantage of their projects.

Thus we propose a number of factors that influence the choice of an appropriate mix of vertical and shared leadership styles. These factors include:

1. The type of project (novelty, technology, pace, and complexity);

2. The stage in the project lifecycle;

3. The level of organisational project management maturity;

4. The level in the hierarchy of a project-orientated organisation, from portfolio through programme, project, and sub-project, down to work package and activity level;

5. The level of trust and collaboration in the team.

We are aware that a number of other factors, such as the technical maturity of team members and greenfields versus brownfields projects, could influence the appropriate leadership balance; but due to scope limitations, these aspects are excluded from the study.

Later in this paper we shall put forward and discuss nine propositions. This will be followed by a conceptual model that may assist researchers and practitioners to understand better the projectrelated factors that influence the balance of vertical and shared leadership, and the effect of an appropriate balance on perceived project performance/success.

\section{FACTORS THAT MAY INFLUENCE LEADERSHIP STYLE}

\subsection{Influence of the type of project on leadership style}

Organisations should recognise that 'one size does not fit all' their projects. Teams should use a 'rolling wave planning' or an 'agile project management style' in which they understand that not everything can be planned in advance [19]. In view of this, projects should frequently adapt to different levels of market, technological, and environmental uncertainty; different levels of intricacy; or different restrictions and boundaries [19]. This typically changes often during the project lifecycle. A project should also be tailored to the specific business environment and industry, as no two businesses or industries are alike.

The 'diamond of innovation' model (Figure 2) suggests a framework for analysing a project's specific setting and for selecting the appropriate project management style. The model has four dimensions: novelty, technology, complexity, and pace. Each dimension is divided into four different project types, and each has a different impact on project management [19]. Since devising the original 
version [20], Shenhar has developed a more complex diamond model, published in 2015 [19]. The latest version [21] is presented in Figure 2.

The four dimensions will described in more detail next.

The 'pace' dimension will be described below in order to explain the first proposition (see Figure 2).

\subsubsection{Pace (How critical is the time frame?)}

The urgency of the project is represented by pace - i.e., how much time is available to complete the project. The scale measuring pace includes the following [19,20,21]:

- $\quad$ Regular refers to projects where time is not critical for immediate success and the project is managed casually.

- Fast/competitive projects are typically those carried out by industrial and non-profit organisations. These projects must be managed with a strategic view, and the emphasis should be on meeting schedules and addressing customer and market needs. Top management should support and closely monitor each important milestone, but they must also be watchful for things going wrong in between.

- $\quad$ Time-critical projects must be completed by a specific date, and missing the deadline implies project failure. The due date is constrained by a fixed event or a window of opportunity. Here time is the most critical factor: all other factors - e.g., budget - are secondary. In order to be prepared to deal with circumstances that might delay completion, contingency plans must be in place.

- Blitz projects are the most urgent and most time-critical; most are in response to a crisis or an emergency, and there is little or no time for detailed planning. Success is measured by the time-frame in which the crisis is solved. Work is performed twenty-four hours a day, with constant decision-making and continuous interaction. All regular bureaucracy is abandoned. The project manager should be given full autonomy, with all team members reporting to this leader. Top management should be available at all times to support, monitor, and make necessary decisions. Hsu et al. [16] state that vertical leadership is more suitable for dealing with emergencies.

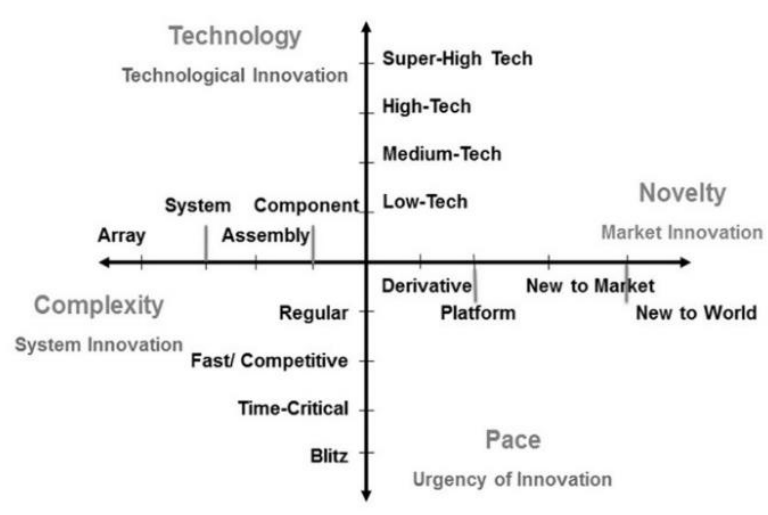

Figure 2: The diamond of innovation - for adapting a project to context [21].

The above leads to the first proposition:

P1: The higher-paced a project, the more the appropriate balance is towards vertical leadership.

\subsubsection{Complexity (system scope)}

This dimension measures the complexity of the product, the tasks, and the project. The scale for complexity includes the following $[19,20,21]$ :

- A component is a single element or part. There is no formality or detailed planning, and little bureaucracy.

- $\quad$ An assembly involves the combination of a collection of elements, components, and modules into a single unit that performs a single function. The product to be developed may be a simple 
stand-alone product (e.g., a CD player) or it could be a subsystem (e.g., an automobile's transmission). Assembly projects are typically technical in nature. There is very little bureaucracy; people often do not submit formal documentation or detailed planning [21].

- $\quad$ System projects work with a multifaceted collection of interactive elements and subsystems. These subsystems together perform multiple functions to meet a specific operational need. Examples of system projects are the development of motorcars and computers, and the construction of large buildings. The management style is more firm and formal. Because system projects require integration of the final product, project management must focus on a combination of technical and administrative issues. System project managers tend to 'bureaucratise' their projects [21]. A study done by Ogbonna and Harris [22] indicated that bureaucratic cultures are characterised by integration, internal cohesiveness, and uniformity. Jaskyte [23] says that cohesive groups with a strong, commanding leader are more likely to pursue uniformity. Here individuals will be careful to express their opinions for fear of scorn and dismissal. It can thus be deduced that vertical leadership is predominantly practised in system projects.

- $\quad$ Array projects (often called 'programmes') involve large, widely dispersed collections of systems that function together to achieve a common purpose. (Sometimes they are called 'systems of systems' or 'super systems'.) An example would be a national communications network, where formality is maximised and bureaucratised. The nature of the project necessitates that it is managed in a very formal way, and that the project manager puts a lot of effort into the legal aspects of the various contracts. Leaders should pay close attention to the social and environmental impact of their projects, and also the views of political decisionmakers. This is because no array project can survive if it loses its political support. When significant external stakeholders (e.g., political decision-makers) are involved, shared leadership is required [21].

We therefore postulate that on complex projects the balance should be more towards shared than vertical leadership. This notion is supported by Hsu et al. [16], who state that the link between shared leadership and team performance becomes stronger when the team's tasks are more complex.

P2: The more complex a project (larger scope), the more the appropriate balance is towards shared leadership.

\subsubsection{Novelty (How new is the product in the market?)}

This dimension represents the uncertainty of the project's goal, or market, or both [19]. It measures the 'newness' of the project's product to customers, users, or the market in general. It gives an indication of how clear and well-defined the initial product requirements are. The management style should be more structured for less novel projects, and more flexible for highly novel projects. More creativity is needed at the higher levels of novelty [19],[21].

Brockhoff [24] found that a standardised project management methodology is not suitable for highly novel projects. He suggested that highly novel projects require significant new knowledge, which increases the importance of team involvement (as tacit knowledge typically comes from the project team). The importance of the roles of top management and the project manager is reduced because the project is prominent in the organisation, and does not need as much attention from top management to maintain its visibility or its priority status. Shared leadership frequently increases teams' creativity and innovation through information-sharing and cooperation [16]. We therefore deduce that highly novel projects rely more heavily on shared leadership. The right people should be chosen for the project [21]. The levels of novelty are the following [21]:

- $\quad$ Derivative products are additions to and advances on existing products.

- $\quad$ Platform products replace older generation products in a fixed market sector - e.g., a new model motorcar.

- $\quad$ New to market - e.g., the first rapid rail transportation system in South Africa (Gautrain).

- New to world products are brand new products that the market and the world have not seen before - e.g., the first portable mobile phone.

The above supports the following proposition:

P3: The higher the novelty of a project, the more the balance is towards shared leadership. 


\subsubsection{Technology}

This is the next dimension of the Shenhar and Dvir [25] diamond model to be discussed:

- Low-tech projects are based on existing and well-established technologies - e.g., regular construction projects where managers should be firm and stick to the original plan [25].

- Medium-tech projects incorporate some new technology or a new feature that was not found in previous products with existing or base technologies. Examples include products in stable industries such as appliances, automobiles, or heavy equipment. Managers should be prepared to accept some changes early on, but after design-freeze they should do everything in their power to get the product ready as soon as possible [25].

- High-tech projects use technologies that are new to the firm but that already exist and are available at the start of the project - e.g., computer and defence development projects (where it is common to use only existing technology in product development). Managers should be prepared to accept many changes, and must wait longer for the final product design. According to Shenhar and Dvir [25], the major flow of information is verbal, and the projects are characterised by regular meetings to solve problems and to share information. The system consists of internal meetings of the project team, the subcontractors, and the customers. There is open communication and constant discussion. In order to strengthen group cohesiveness, managers often arrange team-building exercises [25].

- $\quad$ Super-high-tech projects employ new technologies that are used for the first time. The project mission is clear, but not the solution; therefore new technologies have to be developed during the lifespan of the project [25]. NASA's moon-landing programme of the 1960s would be an example. Managers should master the art of patience, must be used to continuous change, and should make sure that alternative technologies have been evaluated. They should develop a 'look for trouble' attitude [25]. It often happens that the managers of super-high-tech projects are distinguished technical leaders in their organisations, and engineers feel honoured to work for them. The culture is that of an 'elite team' that 'makes a difference' and 'creates the future' [25]. The programme is managed in a very flexible way: many ideas are presented and tested, and a huge number of changes and improvements are made. All team members should share information as soon as it is produced, and not wait for meetings and formal reports to report it [25].

The above supports the proposition that the higher the level of technology involved in a project, the more the balance is towards shared leadership [25]. This can be seen in the leadership style practised in super-high-tech projects, where team members are not held back by meetings and reports to share new information, and the team is managed in a flexible manner with patient managers [25].

The above leads to proposition 4:

P4: The higher the level of technology involved in a project, the more the balance is towards shared leadership.

\subsection{The stage in the project lifecycle}

Patanakul et al. [26] state that the project lifecycle serves as a basic structure for the management of projects, while Turner and Müller [27] say that it is perfectly suitable for a project manager to use different project leadership styles at different stages of the project lifecycle.

The generic project lifecycle in the PMI [28] is as follows:

- $\quad$ Starting the project;

- Organising and preparing;

- $\quad$ Carrying out the project work;

- $\quad$ Closing the project.

Post-project business value must be assessed [29],[30].

Shared and vertical leadership can be used when needed, and should be appropriate to the stage during the lifecycle of a firm or project [2]. Turner and Müller [27] also mention that the phase in the project lifecycle has an influence on leadership style. Patanakul et al. [26] agree, saying that the characteristics and required deliverables of each project stage influence the project 
management activities in that phase, and that it should include leadership style. Ensley et al. [1], Patanakul et al. [26] and Turner and Müller [27] all agree that there is no set leadership style for any particular stage of a project; the leadership style should be appropriately tailored to the lifecycle of a project.

As illustrated in Table 2, we postulate that, in order to facilitate planning and the involvement of a variety of stakeholders, the balance should be towards shared leadership during the early stages (starting the project and organising and preparing). While the execution of different types of project differs, carrying out the work (executing, monitoring and control processes) would in many cases require a somewhat more vertical leadership style. During close-out, shared leadership would again be more appropriate again, because the participation of team members is essential for identifying lessons learned.

The above leads to proposition 5:

P5: During the execution phase, the leadership tends to move towards vertical leadership. During the initial phases, organising and preparing, as well as during close-out and post-project assessment of business value, the leadership style tends to be more shared (see Table 2).

Table 2: Generic project lifecycle stages and the leadership style during each phase

\begin{tabular}{|c|l|l|}
\hline & Balance more towards shared leadership & \multicolumn{1}{|c|}{$\begin{array}{c}\text { Balance more towards vertical } \\
\text { leadership }\end{array}$} \\
\hline $\begin{array}{c}\text { Stage } \\
\text { within the } \\
\text { project } \\
\text { lifecycle }\end{array}$ & 1. Starting the project & $\begin{array}{l}\text { 3. Carrying out the project work } \\
\text { (executing, monitoring, and control } \\
\text { processes) }\end{array}$ \\
\cline { 2 - 2 } & 2. Organising and preparing & 4. Closing the project \\
\cline { 2 - 3 }
\end{tabular}

\subsection{Organisational project management maturity}

A number of project management maturity models $\left(\mathrm{PM}^{3} \mathrm{~s}\right)$ have been developed since the mid-1990s; more than 30 models were available in 2012 [31]. Models include OPM3 (the Organisational Project Management Maturity model) [29], SPICE (Structure Process Organisational Improvement for Construction Enterprises) [32]), and $\mathrm{PM}^{2}$ (Project Management Process Maturity model) [33]). The majority of the models consist of five distinct levels that describe an ordinal scale for measuring maturity [34]. Level 1 is the initial level, in which no project management is done; level 5 is the 'optimising' level, in which the company is fully mature. Figure 3 illustrates the typical five maturity levels. Ika [35] said in 2009 that no single maturity model was recognised worldwide; Yazici [36] found that most organisations do not achieve level 3 or higher.

Torres [37] identifies three major roles of maturity models in organisations:

- $\quad$ Measuring the current state of maturity;

- $\quad$ Providing advice to reach a higher level of maturity; and

- $\quad$ Benchmarking with other organisations.

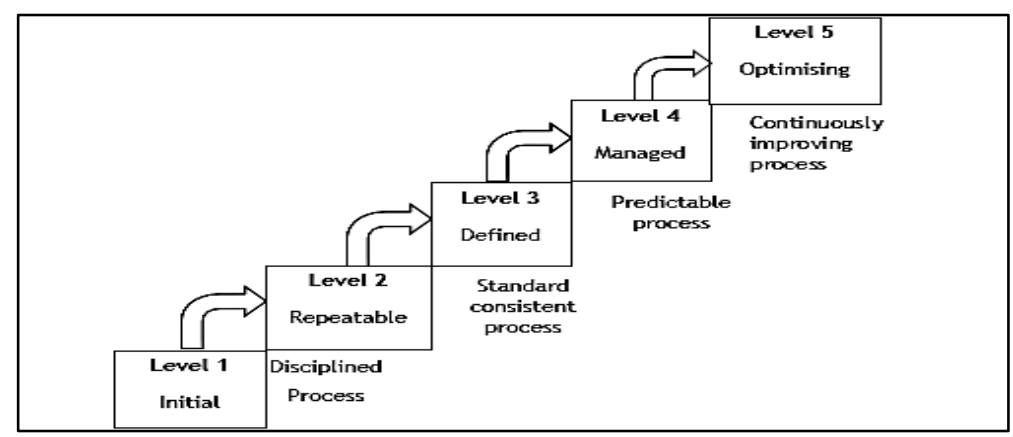

Figure 3: Project management maturity model $\left(\mathrm{PM}^{3}\right)$ [31]

Although maturity models can be useful tools [29], Mullaly [38] asserts that they should not be the beginning and end of the science of maturity. Mullaly [38] criticises project management maturity 
models, stating that there is insufficient evidence that an increase in project management maturity, as it is currently defined, actually leads to an increase in organisational value. Skulmosky [39] suggests, but does not demonstrate, that there is a link between project management maturity and competency. Recent longitudinal studies of organisational maturity have also been unable to prove a clear link between project management maturity and performance [38],[40]. Mullaly [38] further suggests that project management maturity models need to change their focus from just process maturity to a broader cognisance of organisational maturity. Project management maturity models need to be more flexible in their structure, more adjustable in their approach, and more receptive in their applications in order for them to be appropriately relevant and meaningfully useful [38],[40].

Dooley et al. [41] said that maturity means having a well-defined, managed, measured, and continuously improved process. Although certain studies, including research done by Mullaly [38],[40] as discussed in the previous paragraph, failed to prove that high maturity in project management correlates with better results [9]. Dooley et al. [41] disagreed, finding that higher levels of maturity were associated with projects that met organisational goals such as cost goals i.e., projects that perform well. High-performance teams typically execute projects that generally perform well and meet most organisational goals. Studies by Shamir and Lapidot [42] showed that high-performance teams actively engaged much more in shared leadership than did other teams. We thus deduce that high-performance teams are likely to be more mature and to engage in shared leadership. We therefore postulate that mature teams tend to engage in shared leadership.

The above leads to the following proposition (proposition 6):

P6: The higher the level of project management maturity in the organisation, the more shared leadership will be used.

\subsection{The project's position/level within the hierarchy of work in a project-oriented organisation}

Gareis [43] defines project-oriented companies as those organisations that execute small and large projects, as well as unique and standard projects, to deal with new challenges and potential in an ever-changing business environment. The balance between vertical and shared leadership may be influenced by the level within the hierarchy of a project-oriented organisation - i.e., the level within the hierarchy from programme to project and sub-project, down to work package and activity level.

PRINCE2 ${ }^{\circledR}[29]$ indicates that programmes and projects focus on applying change initiatives in the 'correct' manner, while portfolio management selects the initiatives that will realise benefits that contribute to contracted objectives. It seems that strategic decisions would require more shared leadership than work executed at activity level. Management of programmes, and especially portfolios of projects, could therefore be expected to require leadership that is biased towards shared leadership.

However, levels within the project hierarchy are not well standardised; although terms such as project and work package have been standardised to a large extent, some organisations would, for example, use the term task where others would use activity. A set of sub-projects or even work packages of a single, large project can be as complex to manage as a set of several small projects; and what one organisation would consider a large project, another organisation might even view as a programme.

Nicholas and Steyn [44] state that programmes and projects are different: a programme ranges over a longer time than a project, and it also consists of a number of parallel or consecutive projects in order to meet a programme goal. The projects within a programme use common resources and are often interdependent. A portfolio is defined as "projects, programmes, sub-portfolios, and operations managed as a group to achieve strategic objectives" [28].

While programmes and portfolios of projects cannot be regarded simply as higher levels in the project hierarchy [45], the diamond model (described earlier) allows work entities such as projects, sub-projects, work packages and activities all to be measured on the same scales and to be compared with one another, regardless of the terms used to describe them [46]. Addressing the relationship between the types of project, as described by the diamond model, therefore obviates the need to investigate the relationship between leadership style and the level within the project hierarchy. 


\subsection{Organisational structure}

In a classical functional organisation, where each employee has one clear superior, staff members are frequently grouped by speciality, such as production, marketing, engineering, or accounting at the top level [28]. For example, an engineering project may be divided into chemical and electronic engineering. Each department in a functional organisation typically works independently of the other departments. In a projectised organisation, on the other hand, the project manager has the highest authority, but a lower authority in other structures, as indicated in Table 3 [28].

Although one might postulate that structures to the right at Table 3 may tend to require more vertical leadership, this aspect is beyond the scope of this study.

Table 3: The influence of organisational structures on the authority of the project manager [28]

\begin{tabular}{|c|c|c|c|c|c|}
\hline & \multicolumn{5}{|c|}{ Type of organisational structure } \\
\hline & \multirow[t]{2}{*}{ Functional } & \multicolumn{3}{|c|}{ Matrix } & \multirow[t]{2}{*}{ Projectised } \\
\hline & & Weak & Balanced & Strong & \\
\hline $\begin{array}{l}\text { Project } \\
\text { manager's } \\
\text { authority }\end{array}$ & Little or none & Low & Low to moderate & $\begin{array}{l}\text { Moderate to } \\
\text { high }\end{array}$ & $\begin{array}{l}\text { High to almost } \\
\text { total }\end{array}$ \\
\hline $\begin{array}{l}\text { Project } \\
\text { manager's } \\
\text { role }\end{array}$ & Part-time & $\begin{array}{l}\text { Part- } \\
\text { time }\end{array}$ & Full-time & Full-time & Full-time \\
\hline
\end{tabular}

\section{THE LEVEL OF TRUST AND COLLABORATION}

\subsection{Level of trust and leadership style}

Fox [47] says that an environment of trust is crucial to communication, and Kadefors [48] defines 'trust' as a psychological state, not a behaviour, that is 'ambiguous and complex'. The following authors have identified enablers of trust:

- $\quad$ Nicholas and Steyn [44] say that the best way to construct trust is through face-to-face contact. People in virtual teams must get to know each other through meetings that are long enough. The project manager of a virtual team should meet at least once with each person in the team, but ideally more often. Trust typically decreases when team members doubt each other and/or the team leader. It often improves when the group members see their colleagues acting with integrity, performing competently, and showing concern for each other's well-being [49].

- Tyler [50] defines 'trust' as a matter of certainty in which people act based on their anticipations about the likely future behaviour of others. Trust can also be seen as an issue of competence, where people trust only those who they believe can decipher problems and deliver desired outcomes. Trust is important because it typically enables co-operation. People usually have more trust in the motives of people with whom they share a social background [50].

- Carvalho [51] adds that, where there is trust, team members will ask for help, speak openly and reliably, take risks, accept new challenges, and carry out their undertakings with less anxiety or stress.

- Schoorman et al. [52] say that trust is the "willingness to take risk" (i.e., "be vulnerable"). The level of trust frequently is an indication of the amount of risk that an individual is willing to take. When trust is at its lowest level, an individual will take no risk at all.

- $\quad$ For an environment to be conductive to trust, Fox [47] stresses the significance of five actions that ensure a common understanding of concepts, actions, and results:

- Sharing opinions and feelings;

- Assuming obligations that one can fulfil;

- Acknowledging mistakes;

- $\quad$ Asking for and accepting feedback; and

- Identifying and testing assumptions.

- Just as the perceptions of an individual's competencies, benevolence ('the extent to which a party is believed to want to do good for the trusting party, aside from an egocentric profit motive'), and integrity ('will fulfill agreements as promised') frequently have an impact on 
how others trust the individual, these views might also affect the extent to which an organisation will be trusted [52].

The systematic use of these techniques in the organisation inspires their circulation among collaborators.

According to Hsu et al. [16], shared leadership has been found to have better outcomes than vertical leadership in the creation of trust within a team.

The above supports proposition 7:

P7: The higher the level of trust, the more the balance would be towards shared leadership.

\subsection{Degree of collaboration and leadership style}

According to Bond-Barnard et al. [53], collaboration can take place between individuals, or between organisations, or between an organisation and its shareholders. Only interpersonal collaboration is considered in this study. Kadefors [48] says that intuitive and emotional reactions that are sensitive to behavioural aspects, and that show respect and concern, may strongly influence the development of trust and a tendency to collaborate.

Various factors influence collaboration [53]. Tyler [50] says that trust affects performance through the initiation of teamwork or other collaborative processes. Trusting teams can typically manage the interdependencies among their different areas of knowledge better. At an individual level, collaborative work usually predicts task and team performance. Collaboration indicators identified in Bond-Barnard et al. [53] are relationships, coordination, proximity, commitment, conflict, and incentives.

The above literature supports proposition 8:

P8: The higher the level of collaboration, the more the balance would be towards shared leadership.

\section{PERCEIVED PROJECT MANAGEMENT PERFORMANCE / SUCCESS}

Success can mean different things to different people [54]. Müller and Turner [55] say that people judge the success of projects differently, depending on their personal objectives. What is considered a success by one person might constitute a failure for another. According to Bond-Barnard et al. [53], project success is measured by 'things-related' measures such as the budget, quality, and schedule of the project deliverable (which will hereafter be collectively referred to as 'project performance'), and 'people-related' criteria such as communication, trust, and collaboration, which determine the team morale and stakeholder satisfaction in the project, among others [53]. An additional construct, knowledge integration and innovation, influences project success by bridging the gap between the 'things-related' and 'people-related' factors [53].

Müller and Turner [55] show that a project manager's success is reliant on their competence predominantly their leadership style, encompassing emotional intelligence, management focus, and intellect. Several authors, including Muenjohn and Armstrong [56], investigated a variety of leadership concepts such as transactional leadership, transformational leadership, and laissez-faire. These topics are beyond the scope of this paper.

While Müller and Turner [55] studied the success of the project manager, this paper investigates the factors that influence the appropriate balance between shared and vertical leadership, and its influence on project success and performance. The final proposition (proposition 9) addresses this:

P9: The more appropriate the balance between shared and vertical leadership, the higher the perceived likelihood of project management success/performance, as illustrated in the conceptual model. 
Figure 4 illustrates the model based on the propositions described above.

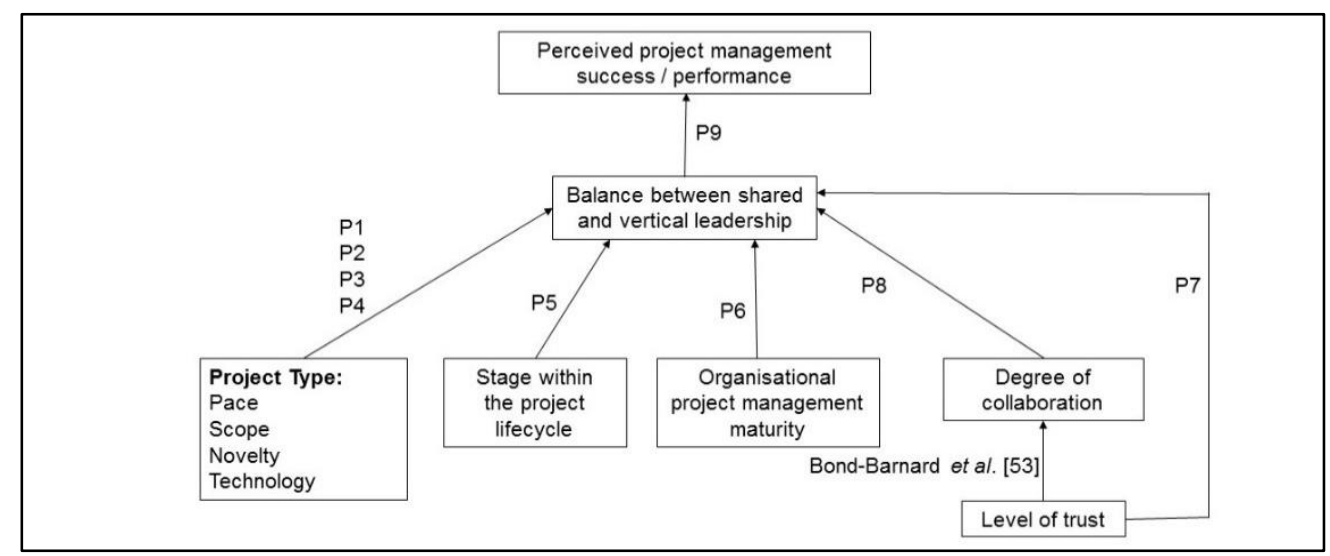

Figure 4: Conceptual model

An aspect not addressed in the model is the following: It might be postulated that sensitive issues that affect people personally (e.g., salaries and retrenchments) would require more shared leadership than non-sensitive issues (e.g., alternative building materials to be used).

\section{CONCLUSION AND DISCUSSION}

Based on a literature survey, this paper presents a theoretical model of project-related factors that influence leadership styles (shared and vertical leadership), and their effect on project performance. The paper puts forward nine propositions that, it should be noted, are not mutually exclusive. The nine propositions are:

P1: The higher-paced a project, the more the appropriate balance is towards vertical leadership.

P2: The more complex a project (larger scope), the more the appropriate balance is towards shared leadership.

P3: The higher the novelty of a project, the more the balance is towards shared leadership.

P4: The higher the level of technology involved in a project, the more the balance is towards shared leadership.

P5: During the execution phase, the leadership tends to move towards vertical leadership. During the initial phases, organising and preparing, as well as during close-out and post-project assessment of business value, the leadership style tends to be more shared.

P6: The higher the level of project management maturity in the organisation, the more shared leadership will be used.

P7: The higher the level of trust, the more the balance would be towards shared leadership.

P8: The higher the level of collaboration, the more the balance would be towards shared leadership.

P9: The more appropriate the balance between shared and vertical leadership, the higher the perceived likelihood of project management success/performance, as illustrated in the conceptual model.

It is planned to determine empirically the particular balances of leadership styles for specific situations that would lead to improved project success/performance. Empirical results will be reported in a sequel to this paper.

A possible shortcoming is that shared and vertical leadership were studied in isolation from the other leadership styles. This could be an opportunity for further research.

Very few studies have modelled project-related factors that influence leadership styles and their effect on project performance. This study attempts to fill this gap through a review of the literature, leading to nine propositions that constitute the theoretical framework proposed in this paper. For 
the practitioner, this model presents a conceptual framework that explores the influence of project types, the stage in the project lifecycle, organisational project management maturity, and the level of trust and collaboration between project team members on the appropriate balance of leadership styles in projects. The framework provides practitioners with novel insights into the role of different project-related factors in determining the correct balance of leadership styles for a particular situation.

\section{ACKNOWLEDGEMENTS}

The authors gratefully acknowledge the valuable contributions and guidance of Prof. Ralf Müller and Prof. Yvonne du Plessis.

\section{REFERENCES}

[1] Ensley, M.D., Hmieleski, K.M. and Pearce, C.L. 2006. The importance of vertical and shared leadership within new venture top management teams: Implications for the performance of startups. Leadership Quarterly, 17(3), pp. 217-231.

[2] Crevani, L., Lindgren, M. and Packendorff, J. 2007. Shared leadership: A postheroic perspective on leadership as a collective construction. International Journal of Leadership Studies, 3(1), pp. 40-67.

[3] Müller, R., Niklova, N., Sankaran, S., Zhu, F., Xiaohang, X., Vaagaasar, A.L. and Drouin, N. 2016. Leading projects by balancing vertical and horizontal leadership - International case studies, in EURAM Conference.

[4] Müller, R., Sankaran, S., Drouin, N., Niklova, N. and Vagaasar, A.L. 2015. The socio-cognitive space for linking horizontal and vertical leadership, in APROS/EGOS Conference.

[5] Müller, R., Zhu, F., Sun, X., Wang, L. and Yu, M. 2017. The identification of temporary horizontal leaders in projects: The case of China. International Journal of Project Management, in press.

[6] Müller, R., Sankaran, S., Drouin, N., Vaagaasar, A.L., Bekker, M.C. and Jain, K. 2017. A theory framework for balancing vertical and horizontal leadership in projects. International Journal of Project Management, in press.

[7] Agarwal, N., Dixit, A., Jain, V., Sankaran, K., Nikolova, N., Müller, R. and Drouin, N. 2017. Exploring vertical and horizontal leadership in projects: A comparison of Indian and Australian contexts, in Accelerating Development: Harnessing the Power of Project Management, PMI, India.

[8] Houghton, J.D., Neck, C.P. and Manz, C.C. 2003. Self-leadership and super-leadership: The heart and art of creating shared leadership in teams, in Shared leadership: Reframing the hows and whys of leadership. Pearce, J.A. and Conger, C.L. (eds), Thousand Oaks, California: Sage Publications, Inc., pp. 123-135.

[9] Müller, R. 2017. Personal communication.

[10] Wood, M.S. 2005. Determinants of shared leadership in management teams. International Journal of Leadership Studies, 1(1), pp. 64-85.

[11] Hoch, J.E. and Dulebohn, J.H. 2013. Shared leadership in enterprise resource planning and human resource management system implementation. Human Resource Management Review, 23(1), pp. 114-125.

[12] Kocolowski, M.D. 2010. Shared leadership: Is it time for a change? Emerging Leadership Journeys, 3(1), pp. 22-32.

[13] Burke, C.S., Fiore, S.M. and Salas, E. 2003. The role of shared cognition in enabling shared leadership and team adaptability, in Shared leadership: Reframing the hows and whys of leadership. Pearce, J.A. and Conger, C.L. (eds), Thousand Oaks, California: Sage Publications, Inc., pp. 103-122.

[14] Northouse, P.G. 2016. Leadership. 7th ed. London: Sage Publications, Inc.

[15] Locke, E.A. 2003. Leadership: Starting at the top, in Shared Leadership. Reframing the Hows and Whys of Leadership. Pearce, J.A. and Conger, C.L. Ed. Thousand Oaks, California, USA: Sage Publications, Inc., pp. 271-284.

[16] Hsu, J.S., Li, Y. and Sun, H. 2017. Exploring the interaction between vertical and shared leadership in information systems development projects. International Journal of Project Management, 35(8), pp. 15571572.

[17] Conger, C.L. and Pearce, J.A. 2003. A landscape of opportunities, in Shared Leadership. Reframing the Hows and Whys of Leadership. Pearce, J.A. and Conger, C.L. Ed. Thousand Oaks, California, USA: Sage Publications, Inc., pp. 285-303.

[18] Zander, L. and Butler, C.L. 2010. Leadership modes: Success strategies for multicultural teams. Scandinavian Journal of Management, 26(3), pp. 258-267.

[19] Shenhar, A.J. 2012. What is strategic project leadership? 2012 PMI Global Congress Proceedings, pp. 1-11.

[20] Shenhar, A.J. and Dvir, D. 2007. Reinventing project management: The diamond approach to successful growth and innovation. 1st ed. Boston, Massachusetts: Harvard Business School Publishing.

[21] Shenhar, A.J. 2015. The SPL way. Mainstream techniques are no longer doing the job: A modern approach is needed. [Online]. Available: http://splwin.com/index.php/the-spl-way/ [Accessed: 20-Jul-2016].

[22] Ogbonna E. and Harris, L.C. 2000. Leadership style, organizational culture and performance: Empirical evidence from UK companies. International Journal of Human Resource Management, 11(4), pp. 766-788.

[23] Jaskyte, K. 2004. Transformational leadership, organizational culture, and innovativeness in nonprofit organizations. Nonprofit Management and Leadership, 15(2), pp. 153-168. 
[24] Brockhoff, K. 2006. On the novelty dimension in project management. Project Management Institute, 37(3), pp. 26-36.

[25] Shenhar A.J. and Dvir, D. 1996. Toward a typological theory of project management. Research Policy, 25(4), pp. 607-632.

[26] Patanakul, P., lewwongcharoen, B. and Milosevic, D. 2010. An empirical study on the use of project management tools and techniques across project life-cycle and their impact on project success. Journal of General Management, 35(3), pp. 41-65.

[27] Turner, J.R. and Muiller, R. 2005. The project manager's leadership style as a success factor on projects: A literature review. Project Management Journal, 36(1) p. 49-61.

[28] PMI. 2013. A guide to the project management body of knowledge (PMBOK ${ }^{\circledR}$ Guide), 5th ed. Pennsylvania: Project Management Institute, Inc.

[29] Office of Government Commerce, UK. 2009. Manage successful projects with PRINCE2 ${ }^{\circledR}$. London: TSO.

[30] Skulmoski, G.J. and Hartman, F.T. 2010. Information systems project manager soft competencies, a project-phase investigation. Project Management Journal, 41(1), pp. 61-80.

[31] Pretorius, S., Steyn, H. and Jordaan, J. 2012. Project management maturity and project management success in the engineering and construction Industries in Southern Africa. South African Journal of Industrial Engineering, 23(Nov), pp. 1-12.

[32] Sarshar, M., Haigh, R. and Amaratunga, D. 2004. Improving project processes: Best practice case study. Construction Innovation, 4(5), pp. 69-82.

[33] Kwak, Y.H. and Ibbs, C.W. 2002. Project management process maturity PM2 model. Journal of Management in Engineering, 18(3), pp. 150-155.

[34] Backlund, F., Chronéer, D. and Sundqvist, E. 2014. Project management maturity models - A critical review: A case study within Swedish engineering and construction organizations. Procedia - Social Behavioural Sciences, 119(2014), pp. 837-846.

[35] Ika, L.A. 2009. Project success as a topic in project management journals. Project Management Journal, 40(4), pp. 6-19.

[36] Yazici, H.J. 2009. The role of project management maturity and organizational culture in perceived performance. Project Management Journal, 40(3), pp. 14-33.

[37] Torres, L.A. 2014. Contingency view on the effect of project management maturity on perceived performance. Thesis, Skema Business School.

[38] Mullaly, M. 2014. If maturity is the answer, then exactly what was the question? International Journal of Managing Projects in Business, 7(2), pp. 169-185.

[39] Skulmoski, G. 2001. Project maturity and competence interface. Cost Engineering, 43(6), pp. 11-18.

[40] Mullaly, M. 2006. Longitudinal analysis of project management maturity. Project Management Journal, 7(2), pp. 62-73.

[41] Dooley, K., Subra, A. and Anderson, J. 2001. Maturity and its impact on new product development project performance. Research Engineering Design, 13(2001), pp. 23-29.

[42] Shamir, B. and Lapidot, Y. 2003. Trust in organizational superiors: Systemic and collective considerations. Organization Studies, 24(3), pp. 463-491.

[43] Gareis, R. 1991. Management by projects: The management strategy of the 'new' project-oriented company. International Journal of Project Management, 9(2), pp. 71-76.

[44] Nicolas, J.M. and Steyn, H. 2017. Project management for engineering, business and technology. 5th ed. New York: Routledge.

[45] Pellegrinelli, S. 1997. Programme management: Organising project-based change. International Journal of Project Management, 15(3), pp. 141-149.

[46] Steyn, H. and Schnetler, R. 2015. Concurrent projects: How many can you handle? South African Journal of Industrial Engineering, 26(3), pp. 96-109.

[47] Fox, S. 2001. Effective communication: Stone-age to e-comm, in PMI. Annual Seminars \& Symposium.

[48] Kadefors, A. 2004. Trust in project relationships - inside the black box. International Journal of Project Management, 22(3), pp. 175-182.

[49] Lee, P., Gillespie, N., Mann, L. and Wearing, A. 2010. Leadership and trust: Their effect on knowledge sharing and team performance. Management Learning, 41(4), pp. 473-491.

[50] Tyler, T.R. 2003. Trust within organisations. Personnel Review, 32(5), pp. 556-568.

[51] Carvalho, M.M. 2008. Communication issues in projects management, in PICMET 2008 Proceedings, pp. 1280-1284.

[52] Schoorman, F.D., Mayer, R.C. and Davis, J.H. 2007. An integrative model of organizational trust: Past, present, and future. Academy of Management Review, 32(2), pp. 344-354.

[53] Bond-Barnard, T.J., Fletcher, L. and Steyn, H. 2017. Linking trust and collaboration in project teams to project management success. International Journal of Managing Projects in Business, in press.

[54] Jugdev. K. and Müller, R. 2005. A retrospective look at our evolving understanding of project success. Project Management Journal, 36(4), pp. 19-31.

[55] Muiller, R. and Turner, R. 2007. The influence of project managers on project success criteria and project success by type of project. European Management Journal, 25(4), pp. 298-309.

[56] Muenjohn, N. and Armstrong, A. 2007. Transformational leadership: The influence of culture on the leadership behaviours of expatriate managers. International Journal of Business and Information, 2(2), pp. 256-283. 